\title{
Jovens (en)cena: arte, cultura e território ${ }^{1}$
}

\author{
Beatriz Akemi Takeitia, Maria Cristina Gonçalves Vicentin ${ }^{\mathrm{b}}$ \\ aDepartamento de Terapia Ocupacional, Faculdade de Medicina, Universidade Federal do Rio de Janeiro - UFRJ, \\ Rio de Janeiro, RJ, Brasil. \\ 'Pontifícia Universidade Católica de São Paulo - PUC/SP, São Paulo, SP, Brasil.
}

\begin{abstract}
Resumo: Este trabalho discute o lugar das invenções estéticas nos modos de subjetivação de jovens em contextos de vulnerabilização e violências. Pretende, ainda, refletir como as ações empreendidas por estes jovens podem transversalizar a discussão entre terapia ocupacional e cultura. Para tanto, trabalhamos com alguns fragmentos de histórias de vida de três jovens engajados em distintos coletivos culturais - sarau de literatura marginal, movimento hip hop e produção audiovisual - nos distritos da Brasilândia e Vila Nova Cachoeirinha, na zona norte da cidade de São Paulo, os quais pudemos acompanhar por meio de incursões etnográficas nas ações culturais que protagonizam ou das quais participam e de entrevistas em história oral. As produções de subjetividades juvenis têm se configurado como um território-vivo marcado por experiências não só de pobreza e violências, mas, sobretudo, de produções coletivas, criativas, formas inéditas de vida tecidas por meio de invenções estéticas na periferia, em que o estigma de ser jovem, negro e pobre dá lugar ao emblema, ao orgulho de ser da periferia. Este lugar-território emblemático aparece em destaque nos coletivos culturais, particularmente no Sarau Poesia na Brasa e no Cinescadão, duas estratégias de arte/cultura que invocam uma forma de resistência, transformando as experiências das violências e vulnerabilizações vividas na periferia em práticas éticas, estéticas e políticas.
\end{abstract}

Palavras-chave: Juventude, Arte/Cultura, Território, Terapia Ocupacional.

\section{Young (in)scene: art, culture and territory}

\begin{abstract}
This paper discusses the importance of aesthetic inventions on modes of youth subjectivity in the vulnerability and violence contexts. It also intends to reflect on how the actions undertaken by these youth can cut across the discussion between occupational therapy and culture. Therefore, we worked with some fragments of life stories of three young people engaged in cultural collective distinctive - marginal literature soiree, hip hop movement and audiovisual production - in the districts of Brasilândia and Vila Nova Cachoeirinha in the north of the city of São Paulo, whose we could follow through ethnographic incursions in protagonized cultural activities or in which they participate and oral history interviews. The youth subjectivities productions has been configured as a live territory marked not only by poverty and violence experiences, but, also by collective and creative productions, a brand new life style through aesthetic inventions in the periphery where the stigma of being young, negro and poor gives place to an emblem: the pride of being from the periphery. This emblematic territory is highlighted in cultural collective, particularly in Sarau Poetry Brasa and Cinescadão, two strategies of art and culture that invoke an experience resistance, transforming the experiences of violence and vulnerability that are experienced on the outskirts, in ethical, aesthetic and policies practices.
\end{abstract}

Keywords: Youth, Art/Culture, Territory, Occupational Therapy.

Autor para correspondência: Beatriz Akemi Takeiti, Faculdade de Medicina, Universidade Federal do Rio de Janeiro, Rua Prof. Rodolpho Paulo Rocco, s/n, Bloco K, Sala 17, Cidade Universitária, Ilha do Fundão, CEP 21910-590, Rio de Janeiro, RJ, Brasil, e-mail: biatakeiti@gmail.com Recebido em Maio 24, 2015; $1^{\text {a }}$ Revisão em Ago. 03, 2015; Aceito em Set. 30, 2015. 


\section{Introdução}

As subjetividades juvenis têm se configurado como um território-vivo (SANTOS, 2000) marcado por experiências que carregam as marcas da pobreza e de diferentes violências e violações de direitos, mas, sobretudo, de produçóes coletivas, criativas, formas inéditas de vida tecidas por meio de invençôes estéticas e performáticas que enunciam um viver na periferia.

Em 2012, como parte do trabalho de doutoramento, acompanhamos três sujeitos engajados em distintos coletivos culturais - sarau de literatura marginal, movimento hip hop e produçáo audiovisual - nos distritos da Brasilândia e Vila Nova Cachoeirinha, na zona norte da cidade de Sáo Paulo, por meio da escrita diarística, de entrevistas em história oral e experimentações etnográficas (TAKEITI, 2014).

Pretendíamos analisar os modos de subjetivaçáo de jovens em contextos de vulnerabilização e violências, mais especificamente os que se forjam por meio de invençôes estéticas.

Para tanto, adotamos como perspectiva de trabalho, além da circunscrição das juventudes em um determinado tempo e numa dada cultura, entender que o modo como as pensamos reflete um campo de lutas tanto teóricas quanto políticas e econômicas (NOVAES, 2006; SPÓSITO, 2009).

De fato, embora o debate sobre juventude tenha se intensificado nos últimos anos, ainda persistem discursos e práticas em relação à juventude pobre que desconsideram as condiçóes sociais específicas que as forjam. De um lado, um discurso que toma os jovens como naturalmente violentos. De outro, um discurso que articula as violências praticadas por eles às condiçốes sociais e históricas do país, reificando, muitas vezes, a associação pobreza-violência (ZALUAR, 1996). Nos dois casos, a juventude é concebida a partir dos problemas que ela apresenta e que afetam e ameaçam a ordem social (ABRAMO, 1994). Tais discursos constroem uma percepçáo estigmatizante de setores da juventude, associando-os sistematicamente à violência.

Buscamos um posicionamento ético-político que evitasse, por exemplo, a polaridade entre juventudes que cometem violências ou que as vivenciam. Entendemos ser importante identificar processos - no caso, modos de subjetivaçáo - que territorializam/ desterritorializam/reterritorializam ${ }^{2}$ (ADORNO, 1993) os jovens nos circuitos da vulnerabilização e da exclusão.

Por se tratar de um campo movente - as juventudes, as vulnerabilidades e violências -, sua apreensão não deve ser tratada de forma fixa, isolada e imutável, mas ser analisada à luz de processos histórico-político-econômico-sociais mais amplos, isto é, de agenciamentos dos quais o sujeito-jovem é efeito. Isto exige abertura total para a cultura que se estuda (LAPLATINE, 2000), bem como exige que a investigaçấo se nomadize com eles (DIÓGENES, 2008).

A pesquisa realizada, além de dar lugar à experimentação etnográfica que privilegiou a aproximação às experiências juvenis no contexto da periferia, buscou trabalhar com as memórias e narrativas de nossos interlocutores, privilegiando a história oral, que permite apreender os fenômenos sociais engendrados na história (MEIHY; HOLANDA, 2010). Vejamos com mais detalhes como a pesquisa foi realizada.

A delimitação do território da zona norte como o locus da pesquisa se deu por duas razóes: o Índice de Vulnerabilidade Juvenil (FUNDAÇĀO..., 2007), que avaliava a situaçáo de jovens nos 96 distritos do município de São Paulo, mostrava o distrito da Brasilândia como um dos territórios com índices significativos de vulnerabilidade. Além disso, o núcleo de pesquisa no qual se inseria a pesquisa de doutorado desenvolvia, à época, parte de suas açôes integradas ao Programa de Reorientação Profissional em Saúde do Ministério da Saúde (PRÓ-SAÚDE), parceria da PUC/SP com a Supervisão Técnica de Saúde da Freguesia do Ó/Brasilândia, intensificando o diálogo das linhas e dos projetos de pesquisa com aquele território. Buscamos conhecer e convidar jovens que estivessem desenvolvendo açôes culturais mais autônomas, autogestionárias, desvinculadas, neste momento, das açôes propostas por organizaçôes não governamentais. Para tanto, buscamos contato com profissionais que conheciam o circuito cultural da periferia e que poderiam intermediar os encontros. Chegamos assim a três jovens: Jorge, robusto, de fala vultosa, se apresenta à pesquisadora como "Jorjāo" da Brasa. Educador social e integrante do Sarau Poesia na Brasa desde longa data. Com forte inserção no seu território, suas ações estavam pautadas na literatura marginal. Já havia publicado vários livros com este coletivo. Além do Sarau na Brasa, circula por outros saraus na cidade e tenta expandir suas açóes para outros territórios como em Pirituba e na zona leste, berço onde passou parte de sua infância.

Fábio, educador com experiência em comunicaçáo comunitária e produtor de curta-metragens, é referência no audiovisual popular local. Idealizador, sócio-fundador e pesquisador audiovisual da Associação Cultural Fábrica de Gênios, e atua no Núcleo Audiovisual Cinescadão. Seu trânsito pela 
comunidade e entre outros jovens é facilitado pela linguagem utilizada no dia a dia de trabalho, a postura juvenil que adota em toda sua produçáo audiovisual, com um forte apelo político e senso crítico das situaçóes da zona norte.

Anderson Jocker é um típico jovem rapper, morador da favela do Flamingo, no Jardim Peri. Também educador social de uma organização náo governamental, universitário, pai de um menino, nas horas vagas trabalha como ajudante geral. Não foram poucas as vezes em que encontrei Anderson assentando a laje da própria casa e dos vizinhos. Engajado politicamente através do hip hop, transforma a ideia do Cinescadáo em uma produção coletiva cultural itinerante na própria "quebrada". Torna-se empreendedor e fundador do "Cinecachoeira", uma espécie de "Cinescadão" na favela onde nasceu e viu a paisagem se transformar.

Buscamos acompanhar os jovens nestas e em outras atividades de seu cotidiano numa estratégia de inspiração etnográfica, compondo um diário de campo. Ouvimos cada um também na modalidade de entrevista em história oral lançando mão de uma escuta atenta à narrativa de fatos que atravessavam histórias da infância, do bairro, as amizades, as violências, a polícia, o coletivo cultural.

Após a transcrição, textualização e transcriaçãa ${ }^{3}$ das entrevistas, passamos a organizar as falas em quadros sinópticos, de modo que pudéssemos nos aproximar dos temas tratados por cada sujeito nos encontros com a pesquisadora. As entrevistas, após transcriadas, foram devolvidas ao sujeito para conferência e seu aceite. Para alguns, como Jorge, elas foram devolvidas mais de uma vez, solicitando da pesquisadora a alteração, quando não apareciam claras, de algumas passagens de sua história. Anderson, após a conferência, sinalizou desejo de tornar público, em livro, a sua narrativa.

Embora as histórias possam identificar o sujeito, por suas particularidades vividas no território onde a pesquisa ocorreu, negociamos com cada um deles a forma de identificá-los e sugerimos a utilização de nomes fictícios como maneira de preservar suas identidades.

Por se tratar de pesquisa envolvendo seres humanos, a pesquisadora se comprometeu a tomar todos os cuidados éticos necessários considerando inicialmente a pactuação com os colaboradores no que se referia à garantia do sigilo das identidades e das informaçôes obtidas, o cuidado quanto à análise e divulgação deles.

Ao adotar estes caminhos metodológicos, dialogando com as pessoas em diferentes territórios, em distintos momentos e circunstâncias, pudemos nos aproximar da juventude na cidade a partir do que Magnani (2002) denominou “[...] de perto e de dentro", cuidando de náo naturalizar os processos sociais. Olhar os jovens na periferia "de outro lugar", a fim de perceber diferentes arranjos, para além de visôes homogeneizadoras, permitiu-nos avançar na compreensão de sujeitos que vão criando, no convívio com variadas situações, diversas invençóes, distintas percepçóes para o território e para a construção de novos modos de existências juvenis.

Nos acercamos assim do lugar-território emblemático da experimentação cultural empreendida pelos jovens da periferia (NOVAES, 2006) que encarnam uma forma de resistência, transformando as experiências das violências e vulnerabilizações vividas na periferia em práticas éticas, estéticas e políticas, como criação ou potência de vida fantástica (DELEUZE; GUATTARI, 1997). Nesta territorializaçāo, o estigma de ser jovem, negro e pobre dá lugar ao emblema, ao orgulho de ser da periferia (REGUILLO, 1991).

Neste texto destacamos, especialmente, duas estratégias de arte/cultura - o Sarau Poesia na Brasa e o Cinescadão -, de forma a evidenciar os processos de subjetivação que aí se forjam. Isto é, as culturas juvenis como modos de resistência/existência de vida, como estratégias de poder que produzem e investem nas potencialidades criativas do político, na defesa de um lugar performático de ser, se inventar e fazer acontecer na periferia.

A partir dessas invençóes que nos mostram os jovens, buscamos pistas para pensar as relaçóes "entre" terapia ocupacional e cultura.

\section{Periferização da cultura juvenil}

A periferia, para os jovens que nela residem, não tem apenas uma conotação geográfica, mas se refere a um território de existência, em que identidades são construídas e reconstruídas cotidianamente, onde há uma contínua e acelerada produção de subjetividades e seus efeitos aparecem nos estilos de vida, na estética ${ }^{4}$ (NARDI; SILVA, 2009) nos vínculos sociais e laços afetivos (NOVAES, 2006). Eles expressam, por meio da música, da poesia, da dança, do desenho, da palavra, a vida e as violências presentes local e globalmente. Esta expressividade estética e singular é coletiva e política, dá visibilidade às redes territoriais e sociais existentes. Estes jovens contribuem para a construção de espaços públicos nas próprias periferias e favelas submetidas às violências $\mathrm{e}$ todas as formas de vulnerabilidades - da privatizaçáo pelo tráfico à escassez de políticas públicas. 
Alguns estudiosos (PAIS, 2006; REGUILLO, 1991; NOVAES, 2006) consideram que podemos conceber as culturas juvenis a partir de duas maneiras: a primeira, que privilegia a leitura das socializaçóes que as ordenam, e a segunda, que privilegia as expressividades performáticas em seus cotidianos e que forjam sociabilidades e subjetivaçôes. A distinção entre as duas perspectivas pode ser compreendida à luz do "espaço estriado" e do "espaço liso". Segundo Silva (2009 apud DELEUZE; GUATTARI, 1997, p. 188):

[...] liso e estriado designam duas formas ou modos de ocupar ou habitar o espaço, sendo liso o que é povoado por acontecimentos, afetos e intensidades; e estriado o que fecha essa superfície para compartimentá-la segundo intervalos definidos e determinados.

Alguns jovens, ao iniciarem na vida adulta, passariam costumeiramente a se adaptar às formas prescritivas das culturas tradicionais. Esta passagem ocorreria, predominantemente, em espaços estriados. No entanto, outros jovens encontram-se sujeitos às culturas performativas que surgem de determinadas "ilhas de dissidência" em múltiplos contornos que constituem os cotidianos juvenis. Ou seja, as culturas juvenis estariam atreladas às linhas de fuga performativas, ao espaço liso, porque na realidade nem todos estariam enquadrados nas culturas prescritivas que a sociedade lhes impóe (PAIS, 2006).

Preferimos dessa forma pensar as culturas juvenis como modos de resistência/existência de vida; como estratégias de luta, de poder que produzem e investem nas potencialidades criativas do político, na defesa de um lugar performático de ser, se inventar e fazer acontecer na periferia.

Os estudos e as pesquisas em torno das culturas juvenis apresentam-se inseparáveis da análise dos processos ligados à globalização, à produção do imaginário, à circulação e à produção de projetos locais (COSTA, 2006; WELLER, 2011). Para Weller, a noção de cultura juvenil constitui parte da cultura de uma sociedade, na medida em que seus atores - os jovens - são vistos como uma categoria social e geracional específica, com autonomia e poder de decisão sobre suas vidas.

Estes movimentos juvenis que surgiram ao redor do mundo - como os anarco-punks, os hippies, os funks, o hip hop - buscaram espaços de identificação, questionando um estilo plástico, de maciça reprodução e "modelização" da própria subjetividade no contemporâneo (ARCE, 1999).

Arce (1999), ao se debruçar sobre as diversas manifestaçôes juvenis da contemporaneidade na América Latina, ressalta que as décadas de 1970 e
1980 colocaram em evidência os jovens das favelas, das zonas e bairros populares. Estes, tomados pelos movimentos afrodescendentes, por exemplo, como forma de recriação e resistência cultural, construíram novos umbrais de adscrição de identidade, novas referências para o jovem da periferia. Mas a irrupção dessas expressões apresentou-se num clima social definido pelo aumento mundial da violência, o que levou a estigmatizaçóes recorrentes sobre os movimentos juvenis, principalmente contra aqueles protagonizados pelo segmento da classe popular.

Se, por um lado, no discurso social os jovens da periferia são reduzidos à imagem ameaçadora de delinquência e crime, associando-os às diversas formas de violência, por outro, as redes socioculturais nas quais eles estão inseridos forjam estratégias estético-políticas mais autônomas com forte participação juvenil. Sua perseguição, seu acossamento e sua proscrição, iniciados durante as décadas de $1970 \mathrm{e}$ 1980, continuam permitindo aos jovens da periferia e dos bairros populares desenvolver novos umbrais de adscrição, definidos por referentes simbólicos de classe ou geracionais (ARCE, 1999).

Assim, no Brasil, a periferização cultural é marcada pelos movimentos funk e hip hop, que emergem da cultura popular urbana em meados da década de 1970 (VIANNA, 1997; HERSCHMANN, 2000; HERSCHMANN; GALVÃO, 2008; MOASSAB, 2011). Ditando um novo estilo de vida juvenil nas comunidades pobres principalmente do Rio de Janeiro e de São Paulo, esta nova "marca" coletiva coloca em evidência a figura do menino pobre da favela e toda a dimensão política destes movimentos que contestam, por meio da música, do grafite, da dança, as contradiçôes da sociedade que pouco oferta espaços e possibilidades para esses jovens usualmente segregados, inferiorizados ou silenciados pelo sistema hegemônico (HERSCHMANN, 2000).

Hoje, mais do que ontem, as culturas ditas marginais têm sido absorvidas não apenas pela comunidade local, mas têm se transnacionalizado, a ponto de tais grupos romperem com as fronteiras nacionais, em que os estigmas agora vão dando lugar também à construção de novos espaços de reconhecimento e pertencimento à cultura urbana juvenil.

[...] se, antes, a 'periferia' era visível apenas como o lugar da infâmia (violências diversas, crimes, tráfico de drogas...), ela passou a expor também um cenário em que se disseminam inventividades artístico-literário-culturalesportiva com produçóes que chegam a escoar para fora dela. Dir-se-ia que se trata de uma expressão de múltiplas singularidades em conexão, realizando movimentos em proliferação que efetivam ultrapassagens de 
fronteiras. A mise-en-scène de uma arte popular parece produzir desdobramentos peculiares na subjetividade de seus habitantes, os quais passam a ter outras posturas diante das infindáveis dificuldades e dilemas produzidos pela insistente condição de pobreza e miséria (TAKEUTI, 2010, p. 14).

É preciso pensar nos modos de subjetivação das juventudes a partir da classe social, articulando-a a outras categorias, como geração, etnia, gênero, política, religiâo, cultura. Tais vetores de subjetivação são também deslocados, reapropriados e reinventados pelos jovens em seu agir cotidiano. Como sinaliza Freire Filho (2007, p. 10),

[...] a vida cotidiana conceituada não somente como um espaço de sujeição e alienação, mas como uma plataforma de fomento e expressão de micropolíticas de resistências.

Para outros autores, os movimentos de resistência dos jovens:

[...] produzem, de maneira indubitável, revoluçóes moleculares, ou seja, forjam mudanças micropolíticas em seus atores e nos cenários onde atuam, afirmam e apontam para novos caminhos e invençôes. Em outras palavras, diferentes experiências empreendidas pela juventude em seu cotidiano configuram práticas de resistência, expressas por meio da música e de outras artes, de micro-organizaçóes coletivas e de redes de solidariedade que escapam aos simples assistencialismo tão em voga no mundo contemporâneo (NASCIMENTO; COIMBRA, 2009, p. 48).

Assim, vejamos duas experimentaçóes juvenis: o Sarau Poesia na Brasa e o Cinescadão - ações ético-estético-políticas empreendidas por coletivos juvenis no território da zona norte de Sáo Paulo -, para em seguida balizar algumas aproximaçóes com os debates agenciados no campo da terapia ocupacional e da cultura.

\section{Os circuitos culturais juvenis na zona norte de São Paulo}

\subsection{Sarau Poesia na Brasa: uma intervenção urbana a partir da literatura marginal}

Sarau é um espaço em que você bota o microfone lá, liga e organiza quem vai falar, quem vai fazer o quê. Quem chega pela primeira vez, nós do coletivo fazemos questão de ir lá trocar uma ideia, conhecer a pessoa. Nosso barato é esse, não ganhamos grana. Quem ganha grana é o dono do bar. Um bar de quebrada, em dias normais, não vende tanta cerveja como num dia de sarau (Jorge).

A ocupação dos espaços na cidade, especialmente na periferia, já não se apresenta como algo inédito. A comunidade em geral, e os jovens na periferia, em particular, fazem da rua o lugar do encontro, da sociabilidade, da produção de novas subjetividades. Outros territórios existenciais (GUATTARI, 2006) se constituem a partir das histórias, das experiências, do fazer acontecer coletivo que se cruzam e gestam no espaço da periferia.

Trata-se aqui da invenção de estratégias para a constituição de novos territórios, outros espaços de vida e de afeto, uma busca de saídas para fora dos territórios sem saída (GUATTARI; ROLNIK, 2008, p. 18).

O Sarau Poesia na Brasa foi criado em 2008 por jovens da Brasilândia. Constitui-se de um movimento cultural de periferia e para ela. É parte integrante de um movimento mais amplo, o da "Literatura Periférica", que ocorre principalmente nas periferias de São Paulo. Nasceu a partir de outras experiências de saraus, como a Cooperifa, o Sarau do Binho, o Elo da Corrente, sem deixar de expressar a originalidade e independência locais. Tem como objetivo produzir e divulgar a arte nesse território e demais lugares por onde os jovens circulam. Constitui-se como um espaço de expressão, discussão e diálogo das pessoas que residem neste lugar e estão em processos de vulnerabilização e violências. As atividades do Sarau ocorrem quinzenalmente no interior de um bar - Bar do Carlito - na própria Brasilândia. Mas em outros tempos, sua realização já ocorreu nas ruas e outros espaços da Brasilândia.

Para o grupo idealizador, os tambores e a oralidade constituem carros-chefes da comunhão do coletivo, que procura resgatar as tradiçóes milenares dos povos ancestrais. Jorge nos dá algumas pistas que, quando se cruzam a outras experiências, nos permitem significar distintas formas de existência da juventude na periferia da cidade. Reunimo-nos para dividir vontades, para recitar,
cantar, falar, denunciar, narrar histórias e o que
a gente vive aqui na periferia. É um verdadeiro
acontecimento. Fazemos oficinas e montamos estes
eventos de saraus iguais àqueles que acontecem na
famosa Cooperifa, na zona sul da cidade, com
Sérgio Vaz. Chama-se Sarau Poesia na Brasa
porque começou neste lugar, mas nos juntamos a
outros grupos para disseminarmos cultura também 
em outros espaços da cidade. Cultura marginal, literatura marginal, cultura de periferia (Jorge).

Literatura marginal tem sido uma expressão recorrente entre os escritores da periferia para evidenciar uma forma de produção literária que marca uma posiçáo dos autores no mercado editorial, um tipo de linguagem apresentada nos textos e uma escolha dos protagonistas, cenários e situaçóes presentes nas obras literárias. Para Nascimento $(2006)^{5}$, diante de diferentes abordagens, a literatura marginal se tornou uma "assinatura" amplamente utilizada por seus idealizadores, inserindo escritores da periferia no mercado editorial, caracterizando os produtos literários, enaltecendo a condição social do escritor. Por forjar diferentes manifestaçôes, a literatura marginal configurou-se em uma categoria analítica, ajustando desde estudos de biografias isoladas àquelas produzidas por grupos de escritores cujas trajetórias literárias se organizam em torno da expressão cultural.

Embora tal categoria analítica tenha sido amplamente utilizada entre as décadas de 1960 e 1970, é somente a partir de 2001, com Ferréz, que a expressão toma fôlego e se abre para outros territórios periféricos e existenciais (NASCIMENTO, 2006).

Jorge e outros jovens do Sarau Poesia na Brasa, ao afirmarem a literatura marginal como modo de vida que se encarna na periferia, invocam com o coletivo uma forma de resistência diante das desigualdades e diferenças. Inscrito no interior do Bar do Carlito, como mostra a Figura 1, o grupo reafirma outros modos de ser e dizer da favela. É a partir das experiências de violências e vulnerabilidades que as palavras vão tomando corpo e se transformando em linguagens artísticas, compondo poesias, letras

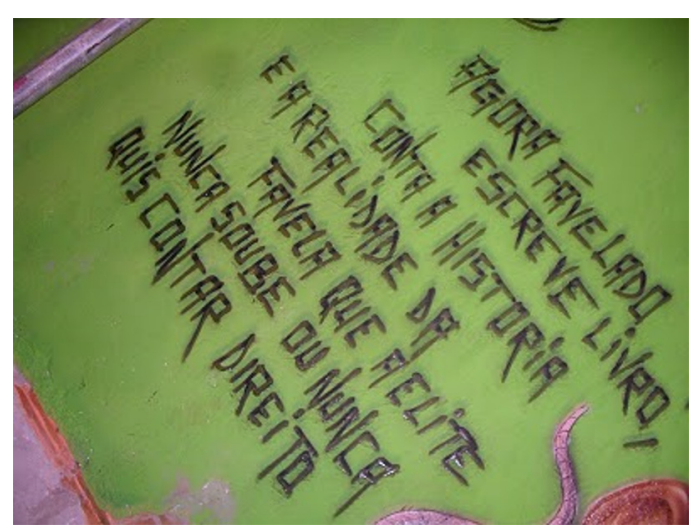

Figura 1. Inscrição grafitada na parede do Bar do Carlito, onde ocorre o Sarau Poesia na Brasa, 02.02.2012. de música, cartas-manifestos. A literatura forjando múltiplos modos de viver a/na periferia.

Jorge da Brasilândia inventa, no encontro com outros corpos juvenis, distintas realidades, múltiplas lógicas urbanas, não reduzindo a própria vida a processos reativos. Pelo contrário, ele estabelece conexôes e vínculos diversos com um viver criativo, pactuado com o grupo social através da busca de caminhos contestatórios e resistentes, novos significados são construídos, diferente relação com a vida é pensada, uma outra narrativa do jovem da periferia é produzida.

Criamos a literatura andante, que consistia em chamar as pessoas para participarem do Sarau na Brasa batendo tambores nas imediaçóes onde o evento aconteceria. E fomos como se fosse um cortejo. Quando a gente começou a bater o tambor, o pessoal, no inicio, achava que era de alguma religiäo. Com os batuques na porta de casa, quem não participava começou a entrar na roda e frequentar o sarau no bar. As pessoas que já frequentavam diziam: - são meninos bons, não vão matar ninguém lá no bar, não vai dar briga, não vai ter nada. Só querem fazer o sarau acontecer. Passamos a ver crianças, senhorinhas, famílias inteiras dentro do bar. Porque é assim: quando vê o povo do sarau, o coletivo passando, um bando de homens cabeludos, barbudos, tatuados, o pessoal acha que ézoeira, povo fumando maconha, usando drogas, traficando, falando um monte de besteira. Mas, quando se vê que é outro tipo de público, que tem criança, gente de família inteira, jovens, acaba quebrando o preconceito, desmistificando a ideia de bar, como um ponto de cultura também. Agora o sarau já faz parte da rotina do bairro e ocorre em botecos e até na rua. Acabamos conquistando esse espaço, que é o nosso coletivo (Jorge).

Mais uma forma inventiva de convocar a comunidade para a participaçáo no Sarau na Brasa a partir do batuque dos tambores. Essas interaçóes socioculturais significam os espaços e os territórios existenciais, carregando de novos sentidos as relaçóes que o referido coletivo estabelece entre os jovens e a comunidade da qual fazem parte (TAKEUTI, 2012). Bar de "quebrada" passa a ser também, para esse tipo de coletivo juvenil, um ponto de cultura, de sociabilidade, de troca de saberes, de produçáo de novas ideias.

Outras produçôes de subjetividade são incorporadas a partir do que reivindicam esses jovens, com seus desejos, aspiraçôes e sonhos, muitas vezes contrapondo-se a perspectivas dominantes de massificação e alienação cultural.

\subsection{Cinescadão como outra via de}




\section{existência juvenil na periferia}

O Cinescadão é um dos eventos em audiovisual e cultural promovidos pela Associação Fábrica de Gênios. Esta Associação constitui a junção de vários outros coletivos: a Fabicine (A Fantástica Fábrica de Cinema) ${ }^{6}$ e os grupos de hip hop Ca.Ge.Be. (Cada Gênio do Beco) e Esbomgaroto, com identidade definida na área de cultura voltada à comunicaçấo audiovisual. Visa a promover e contribuir para formação da cultura de crianças, adolescentes, jovens e adultos, na direção de garantir políticas públicas intersetoriais e romper com o ciclo da violência.

Por volta de 2005 [...] começou a Fabicine - A Fantástica Fábrica de Cinema. Fizemos um projetinho e em 2006 fizemos uma oficina pelo VAI7 (Programa de Valorização de Iniciativas Culturais, Sáo Paulo). O objetivo deste projeto era inaugurar o cineblube Sapocine. Compramos câmera, começamos com uma experiência audiovisual na prática. E ali a gente começou a criar uma relação mediada pelo audiovisual. Porque diferente de outros registros, o audiovisual traz uma outra linguagem, mesmo que a pessoa se posicione, elabore, com toda uma concentração, com suas escolhas, uma vez dito, registrado, você tem outra forma de documentação (Fábio).

A Associação tem realizado intervenções urbanas culturais nos segmentos da música, das artes plásticas de rua, da fotografia, da produção, difusão e exibição audiovisual popular, além de produzir eventos e manifestaçôes culturais, boletins e informes das atividades ocorridas em diversas localidades dos distritos da Brasilândia e Vila Nova Cachoeirinha, particularmente nos bairros do Jardim Peri, Jardim Peri Alto, Jardim Peri Novo e Jardim Antártica.

Nestas conversas aqui na quebrada, pensávamos em estratégias de se criar uma conexão audiovisual na cidade a partir das realizaçōes e das açôes culturais em torno do cinema e vídeo que estes grupos desencadeavam, porque eram grandes zonas de informação para o audiovisual que estavam se formando. O que fizemos foi pensar e montar núcleos de audiovisual na cidade e tentar integrar o circuito de exibição. E por aí tudo comę̧ou. Aqui na zona norte, na Brasilândia, a Vanice foi uma das pessoas que começou a fazer este rolê audiovisual, com pessoal do 'Arroz, Feijäo, Cinema e Vídeo'. Dentro destas nossas experiências, conseguimos fazer com que o pessoal voltasse a estudar e, ao invés de realizadores de audiovisual, hoje são professores (Fábio).

Dispositivos inventivos que contribuem para a construção de novos territórios existenciais e produzem novos sujeitos, a partir da empreitada em itinerários profissionais. Nem todas as iniciativas juvenis redundam em êxito para a grande maioria da população pobre da periferia, que anseia por mudanças significativas e concretas para a sua vida. Entretanto, pode-se afirmar que tais experiências "deixam marcas" no sentido de um outro "devir" juvenil, suprindo algumas das necessidades desses jovens que se engajam nas dinâmicas coletivas e participam das lutas sociais locais (TAKEUTI, 2010).

As experiências negativas vivenciadas por eles não provocam efeitos de paralisação ou inércia social. Pelo contrário, concorrem para estimular mudanças micropolíticas nos sujeitos e espaços destituídos de toda sorte de suprimentos materiais e simbólicos.
A oficina de vídeo popular na quebrada reúne muita gente. É uma experiência legal, interessante para falar de cinema, pensar o audiovisual como arte, mas também como expressão da cultura de periferia. As pessoas precisam passar por esta experiência audiovisual. Quando, dentro dessa experiência, algumas pessoas que já tinham o audiovisual como uma questão pessoal se desenvolvem criativamente, descobrindo esta via como realizador, pronto, está ai mais um parceiro no rolê. É, simplesmente, como fazer uma oficina de literatura, em que você tenta sensibilizar uma galera para as artes literárias. De repente alguém comę̧a a se ligar (Fábio).

As aproximaçóes com o coletivo da Associação e com o Cinescadão foram sempre mediadas por Fábio, que foi me apresentando os territórios do Jardim Peri e me colocando em contato com outros jovens. Um deslocamento da pesquisa acontecia naquele momento, pois as incursóes pelo local, o convívio com as pessoas e a participação nos eventos do "escadáo" enunciavam outros modos de refletir a juventude na periferia, sendo agenciados por diferentes caminhos, distintas lógicas de compreensão do jovem, dos processos de vulnerabilização e das violências na direção das resistências e novas invençôes de vida.

Fábio explica o que o fascinava. Mais do que o cinema, vibrava com os modos de produção, exibição, ambientação dos filmes, além do que o dispositivo audiovisual na quebrada poderia funcionar como um operador também político, na medida em que, ao se criar conteúdo, informação, acenaria para uma mudança no tecido social: a periferia. Um verdadeiro ritual urbano. Pensava na possibilidade de explorar tal ideia no local onde vivia, pois ali seria possível que ela se concretizasse.

O que mexeu comigo, mais do que o filme, foi a sala de cinema. Eu não sabia disso, só mais tarde 
fui entender a importância da sala de cinema, do ambiente de projeção para o espectador. É um ritual, é um ritual urbano, que tem a ver com as sociedades modernas [...]. Eu curtia fazer filme. Queria mostrar para as pessoas, queria discutir esta coisa do compartilhamento, tinha esta preocupação política, inspirada na cultura punk, de criar conteído, informação. E, principalmente, material de luta. Era uma ideia que estava perto da cultura punk. Na realidade, queria entender a cultura cinematográfica, nunca tinha visto um filme [...]. O negócio é exibir filme. Montar estes espaços cineclubistas onde você vai conseguir fazer sua formação e se realizar. Foi um pontapé inicial para desenvolver toda uma reflexáo de cultura audiovisual. Com o tempo, você vai amadurecendo esta ideia, conhecendo o cinema brasileiro e outras experiências. Foi assim que chegamos na experiência do "Cinescadão" [...]. Foi na conjugação dessas ideias todas da minha formação, das conversas com uma amiga socióloga e de um processo que já acontecia na cidade que chamava 'video de periferia', aquela coisa do cinema de quebrada que o Cinescadão se implantou aqui no Peri (Fábio).

Não há como falar de arte/cultura na periferia sem fazermos menção ao papel estético-ético-político do movimento hip hop entre a juventude pobre marginalizada. Movimento potente que aquece o debate e se traduz na poesia ritmada de jovens artistas.

Historicamente, o hip hop foi apropriado predominantemente por comunidades negras dos subúrbios nova-iorquinos. Momento oportuno para esse tipo de movimento, que vivia um crescimento urbano industrial, com efeitos nocivos à população afrodescendente, marginalizada na participação desse progresso (ROSE, 1994 apud WELLER, 2011).

É no bojo das lutas por direitos civis e políticos pelos negros americanos que o hip hop se espalha rapidamente pelas periferias do mundo, numa relação estreita com cada território onde se desenvolveu. Tradicionalmente conhecido como "cultura de rua", e como modo de articulação das vozes reprimidas e marginalizadas dos jovens residentes nos subúrbios americanos, a cultura hip hop associa-se às experiências de ruptura, descontinuidade biográfica e formas de opressão que persistem na sociedade pós-industrial (WELLER, 2011).

Este preconceito em relação ao rap é devido ao lugar onde ele foi criado e é cantado - a quebrada, na periferia. Faziamos grafite em lugares públicos, muros de escolas, becos e vielas das favelas. Acho que era uma forma de desabafar tudo que passávamos naquele lugar (Anderson).

As expressões culturais juvenis se configuram em importantes mecanismos de aglutinação de sociabilidades, práticas coletivas e interesses comuns (TRASSI; MALVASI, 2010). Ganham papel de destaque porque disseminam, por meio da linguagem cultural, realidades da periferia pouco visíveis e se tornam potentes veículos de comunicação, pois desalienam e aquecem o debate entre os jovens porque denunciam as desigualdades, as discriminações sofridas e vivenciadas por parcela da população. Geralmente nomeada como literatura marginal, tais manifestaçôes culturais apostam numa construção coletiva de uma subjetividade juvenil movida pelo desejo de expor suas ideias, preocupaçóes e a vida vivida na cidade.

O Sarau na Brasa e o Cinescadão, assim como tantos outros coletivos periféricos, têm sido considerados dispositivos que operam nas materialidades do poder, em que os corpos juvenis são agenciados coletivamente através da arte, da música, da literatura, da dança numa expressão contrária e de reversão dos assujeitamentos, vulnerabilidades e violências que percorrem cotidianamente a vida desses jovens. Como diz Nascimento e Coimbra,

[...] a juventude afirma outras formas de funcionamento e de organização, estranhas a acordos preestabelecidos. Cria e inventa outros modos de vida, resistindo teimosamente às padronizaçôes, modelizaçóes, patologizaçóes e criminalizaçóes que vivenciam diariamente em seu cotidiano, e por isso conseguem, muitas vezes, escapar ao destino traçado pela lógica do capital, entendida como algo inexorável e imutável (NASCIMENTO; COIMBRA, 2009, p. 48).

Sem a pretensão de pensar tais empreitadas juvenis como verdadeiras revoluçóes, esses agrupamentos coletivos funcionam como movimentos sociais de resistência que forjam mudanças micropolíticas em seus atores e nos cenários onde atuam, afirmam e apontam para novos caminhos e invençôes. Resistências estas devendo ser compreendidas não como uma reação ao poder dominante, às regras ou normas impostas pela sociedade, mas como uma forma de (re)existir, produzir novas subjetividades, novos territórios, como produção de vida (NASCIMENTO; COIMBRA, 2009). Afirmação de outra política pública e de vida da juventude brasileira.

\section{Arte/Cultura como resistência ou como gestão da população juvenil?}

Nestse cenário de transformações socioculturais mais amplas, novos lugares são construídos para o 
jovem que se articula em torno da cultura. Vimos como as experiências, tanto da literatura marginal, expressa por meio do Sarau Poesia na Brasa, quanto o do movimento hip hop e do audiovisual popular empreitado pelo Cinescadão, produzem outras invençóes e subjetividades juvenis na periferia da cidade. No entanto, consideramos importante problematizar certas funçóes do dispositivo cultura na gestáo da população jovem. Vejamos o alerta de Dayrell:

Se a cultura se apresenta como espaço mais aberto é porque os outros espaços sociais estão fechados para eles. Não podemos cair numa postura ingênua de supervalorização do mundo da cultura como apanágio para todos os outros problemas e desafios enfrentados pelos jovens pobres. No contexto em que vive, qualquer instituição pouco pode fazer se náo estiver acompanhada de uma rede de sustentação mais ampla, com políticas públicas que garantam espaços e tempos para que os jovens possam se colocar de fato como sujeitos e cidadãos, com direitos a viver plenamente a juventude (DAYRELL, 2007, p. 173).

Jorge, um dos jovens interlocutores deste estudo, já afirmava em sua fala que os parcos investimentos no bairro da Brasilândia e em outros espaços afora decorrem da mobilização de coletivos criados pelos próprios jovens moradores desse território. Esse dispositivo funciona apenas como "um paliativo", e as pessoas que dele participam colocam em cena não só a vida cotidiana, as carências, a falta, mas também as potências do lugar. Dáo visibilidade às cenas cotidianas e fazem ecoar para o restante da cidade as dificuldades e os problemas enfrentados.

A veia cultural não apaga o incêndio que foi criado desde que vivo aqui. Serve como resposta para determinadas situaçôes de violência vividas e presenciadas por nós, 'jovens, pretos e pobres'. As nossas açōes culturais, como o sarau de literatura, reúnem pessoas de todos os locais, da periferia de São Paulo e mais daqui da Brasilândia [...]. Mas estas atividades artísticas em que estamos engajados e engajam outros jovens não alteram realidades nem a necessidade do dia a dia das pessoas, é só um paliativo para sanar um rombo aberto em que muitos jovens estão mergulhados (Jorge).

Compartilhamos com Dayrell da ideia de que as atividades de arte/cultura precisam estar acompanhadas de uma mudança nas estruturas e conjunturas políticas do país. Do mesmo modo, repercutimos as críticas de Tommasi (2011) ao que se convencionou chamar de “jovens de projetos”: Quais foram os fatores que contribuíram para que estes

[...] jovens tomassem a cena pública $\mathrm{e}$ provocassem tal visibilidade? Foi a capacidade de seus protagonistas ou uma conjuntura política favorável? Foi conquista ou concessão? (TOMMASI, 2011, p.17).

Esta autora tem se debruçado sobre tais questóes, trazendo à luz os usos que ONGs, empresários e governantes têm feito da arte/cultura como empreendimento social e, consequentemente, fazendo a gestão da conduta das populaçóes juvenis. Hoje, temos presenciado os artistas da periferia disputando um lugar no mercado. Se a "cultura de periferia" virou produto, uma marca, uma etiqueta que se exporta para o restante do mundo, esses mesmos artistas estão se beneficiando e colaborando com a produção dessa venda.

Mas, como vender sem fazer desaparecer o conflito, a carga de ruptura, a crítica à ordem vigente? Como não ser cooptado pelas grandes empresas, nichos de mercado, perdendo o valor e os ideais de mudança que a arte/cultura pretende provocar? (TOMMASI, 2011, p.17).

Para Velazco e Tommasi (2013), a valorização dessas culturas de periferia, como parte da produção de um novo regime discursivo, busca promover o "encontro", cada vez mais intensificado, do centro com a periferia, da favela com o asfalto, no caso do Rio de Janeiro. Em São Paulo, por exemplo, vimos algumas iniciativas acontecerem, como ONGs que têm promovido açóes visando à divulgação de uma agenda cultural da periferia. Alinhando-se às políticas públicas de cultura, têm disseminado a estratégia de construção de Pontos de Cultura pela cidade, como uma tentativa de divulgação e aproximação de vários artistas periféricos, favorecendo as trocas sociais e culturais entre os demais coletivos.

Entretanto, Yúdice (2013) nos alerta sobre os usos da cultura na era global e analisa, minuciosamente, seus efeitos nas distintas esferas da política e economia, o que a torna uma noção convencional esvaziada de sentido. Para ele,

[...] a cultura está sendo crescentemente dirigida como um recurso para a melhoria sociopolítica e econômica, ou seja, para aumentar a participaçáo nessa era de envolvimento político decadente, de conflitos acerca da cidadania e do capitalismo cultural. A relação entre a esfera cultural e a política ou cultural e econômica não é nova. Por um lado, a cultura é o veículo do qual a esfera 
pública emerge no século XVIII, e, como argumentam os estudiosos de Foucault e dos estudos culturais, ela se tornou um meio de internalizar o controle social, isto é, via disciplina e governamentalização, ao longo dos séculos XIX e XX (YÚDICE, 2013, p. 26).

Fábio faz críticas contundentes ao mercado audiovisual, indicando que este movimento na quebrada tem rompido com os processos coletivos de intervençóes urbanas.

Vários grupos de audiovisual na cidade estão passando por uma crise, se desmanchando, se desfazendo, rompendo. Muita gente se jogou só pela questão do empreendedorismo e, de repente, ganhou sem ter que se curvar para qualquer emprego. Principalmente aquela galera que não pensava em carreira nem nada. Mas o mercado audiovisual é muito cruel. Muito diferente da cultura audiovisual, que lida com o corporativo. As formas de trabalho são muito diferentes. O vídeo, por exemplo, é muito dependente da propaganda, então fica escravo disso. É muito sujo. E se você caminha nesta direçäo, já deve imaginar o que pode acontecer (Fábio).

Segundo Tommasi (2012) e Velazco e Tommasi (2013), a abertura para os empreendimentos coletivos juvenis tem sido acompanhada de um campo de possibilidades que extrapola as açóes de grupos, estendendo-se também para a comunidade local. Isso significa, nessa lógica de mercado da cultura, a organização desse campo, com oferta de possibilidades de inserção que são altamente regulados, agenciados, conduzidos, num processo que Foucault (2008) denominou de governamentalização, isto é, no saber político da regulação das populaçōes, como verdadeira "arte de governar", gerir coisas e pessoas, conduzir as condutas dos sujeitos em uma dada sociedade.

Assim, no neoliberalismo contemporâneo, os Estados têm enfatizado a atenção na forma de conduzir a vida das pessoas, por meio de iniciativas públicas, como programas, projetos e serviços, particularmente aquelas consideradas mais vulneráveis, agindo sobre o meio, dispondo as coisas na busca por aumentar os elementos positivos e diminuir os riscos (VELAZCO; TOMMASI, 2013).

Nessa perspectiva, os dispositivos acionados no campo da juventude e da arte/cultura procuram organizar esse meio, na direção de traçar os caminhos a serem trilhados, as açôes a serem empreendidas, as palavras de ordem a serem defendidas.

Agora no coletivo da Brasa estamos montando uma organização que vai se chamar Agência de Desenvolvimento Social (AGENTES). Está sendo criada em parceria com o pessoal de Perus, Pirituba, Brasilândia e do Cicas (Centro Independente de Cultura Alternativa e Social) na Vila Sabrina. Desejamos criar essa organização para produzir arte visual na gráfica, música em estúdio. Sabemos das nossas responsabilidades, ao mesmo tempo temos a plena consciência de que não temos esta obrigatoriedade. A obrigação não é nossa, mas do Estado. O pessoal às vezes fala que o hip hop tem que fazer, fazer ou que o movimento de arte nas quebradas tem que provocar mudança. Quem tem que proporcionar tudo isso é o Estado, essa coisa de leitura, quem tem que fazer é o Estado [...] queremos investir na geração de renda para os jovens. Porque existem várias pessoas formando ONGs, pegando dinheiro em nosso nome. Penso que se ela tem que existir, ela tem que estar na nossa mão. Havia alguns editais públicos de arte que nunca pegávamos, porque outras ONGs sempre chegavam na frente. Eo retorno para a comunidade? Nenhum! [...] Nesses quatro anos de intervenção, já publicamos quase onze livros na Brasa. Pensamos: Por que não montamos uma gráfica? Poderíamos empregar vários jovens pagando trezentos reais por mês ou até mais. A ideia é criar organizaçóes que sejam de capazes de produzir renda própria (Jorge).

Vimos constantemente os grupos se organizarem e fazerem "seus corres" em busca da legalização de seus coletivos visando à obtençấo de recursos para a viabilização de seus projetos. Todo mundo está correndo atrás de editais ou abertura de suas organizaçóes para que a ideia, ainda que cara à população juvenil, possa sair da utopia e se tornar realidade, provocando mudanças micropolíticas na vida de outros jovens. Será esse o caminho da (re) invenção da vida na periferia?

\section{Juventude, arte/cultura e Terapia Ocupacional: algumas conexões possíveis}

Muitas são as relações de poder que investem e inventam modos de ser jovem na periferia, seja em relação ao território onde as vidas são tecidas e agenciadas pela insuficiência ou pela ameaça das condições sociais que as vulnerabilizam, ou pelas práticas inventivas empreendidas, como estratégias de luta, táticas cultivadas no decorrer da vida.

Poderíamos afirmar que esses jovens exercem diariamente seus direitos de cidadania cultural como tem proposto Chauí (2008), na medida em que se inserem ativamente em seus territórios, produzem-se como sujeitos e inventam formas de participaçáo social nos circuitos culturais e políticos. Ao assumirmos 
a cultura como uma construção histórico-social mais ampla, podemos afirmar que tais expressóes estético-culturais são um campo propício para o debate e a produção de sentidos quanto à justiça, liberdade, emancipação e reconhecimento. A partir desses coletivos, esses jovens formulam pautas, organizam-se em torno das políticas públicas de fomento de arte/cultura, engajam-se e engajam outros jovens nos circuitos culturais, invocando participaçóes nos diversos espaços públicos. As tecnologias de arte/ cultura têm sido agenciadas como ferramenta de inclusão, participação, engajamento político, gestão e fruição das ações sociais e culturais locais.

Elas encarnam dimensôes ética, estética e política (GUATTARI, 2006), pois: por meio do exercício do pensamento, avaliam situaçóes e acontecimentos, afirmam escolhas e caminhos como potencializadores de vida; exercitam a dimensão da invenção criativa, já que não há conhecimentos universais para serem aplicados, mas uma diversidade de injunçôes que desafiam o pensamento, a ação e a sensibilidade para a produçáo de novos processos de existência e produzem novas práticas, responsabilizando-se pelos efeitos produzidos, por meio de compromissos e riscos implicados com as tensôes e as posiçôes assumidas.

Assim, as açóes territoriais nesse cenário ético-estético-político têm convocado terapeutas ocupacionais a repensar seu papel profissional, deslocando seu saber técnico no diálogo com os saberes plurais.

Se por um tempo indagamos o lugar do social na constituição dos campos da terapia ocupacional e como se dava a construçáo do campo social na terapia ocupacional (BARROS; GHIRARDI; LOPES, 2002; GALHEIGO, 2003; BARROS; LOPES; GALHEIGO, 2007), hoje importa-nos também refletir que lugar tem assumido a cultura nos debates, na construção de tecnologias sócio-ocupacionais, nas estratégias ético-estético-políticas da terapia ocupacional.

Não são poucas nem tampouco recentes as experiências de terapeutas ocupacionais imersas no campo da cultura (COSTA, 2001; DORNELES; PASIN; FONSECA, 2005; MACEDO; BARROS, 2010; COSTA, 2012; BARROS et al., 2013). Embora haja uma consonância destes trabalhos em problematizar questóes de ordem sociocultural junto a determinados segmentos populacionais, há ainda certa necessidade de delinear melhor as ferramentas teórico-conceituais, os recursos e tecnologias sociais e as políticas públicas - sociais e culturais - com as quais se pretende dialogar para fomentar possibilidades de construção do campo da terapia ocupacional e da cultura.
A partir das experiências que acompanhamos entre os jovens, é possível extrair algumas pistas para pensar a terapia ocupacional nesta interface com o cultural: não se trata de pensar a cultura como um âmbito de atuação (como a terapia ocupacional na saúde ou no social); muito menos como técnicas de intervenção que privilegiaram a dimensão estética, mas como um dispositivo transversal aos diversos campos e modos de se fazer e se reconhecer na terapia ocupacional que engaja a produçáo de efeitos ético-estéticos e políticos.

Isto é, se a terapia ocupacional puder dialogar com as experiências juvenis de que falamos, é exatamente afirmando uma perspectiva ética, estética e política para construir seu campo: afirmando escolhas e caminhos como potencializadores de vida (ética); exercitando a dimensão da invenção criativa (estética) e responsabilizando-se pelos efeitos produzidos (política).

Talvez não tenhamos as respostas para o que refletimos e debatemos neste momento. Mas certamente as experiências da terapia ocupacional no âmbito da cultura ao longo destes anos, somadas às políticas públicas culturais tão em voga hoje, poderão apontar outras pistas interessantes e possíveis na constituição de um campo de ação e de produçáo de conhecimento. Como nos disse Foucault (1984) certa vez, pensar e perceber diferentemente do que se pensa e se vê é indispensável para continuar a olhar ou a refletir (p. 12).

\section{Referências}

ABRAMO, H. W. Cenas juvenis: punks e darks no espetáculo urbano. São Paulo: Scritta, 1994.

ADORNO, S. O. A experiência precoce da punição. In: MARTINS, J. S. O massacre dos inocentes: a criança sem infância no Brasil. São Paulo: Editora Hucitec, 1993. p. 181-208.

ARCE, J. M. V. Vida de barro duro: cultura popular juvenil e grafite. Rio de Janeiro: Editora UFRJ, 1999.

BARROS, D. D. et al. Cultura, economia, política e saber como espaços de significação na Terapia Ocupacional Social: Reflexóes sobre a experiência do Ponto de Encontro e Cultura. Cadernos de Terapia Ocupacional da UFSCar, São Carlos, v. 21, n. 3, p. 583-594, 2013.

BARROS, D. D.; GHIRARDI, M. I. G.; LOPES, R. E. Terapia Ocupacional Social. Revista de Terapia Ocupacional da Universidade de São Paulo, São Paulo, v. 13, n. 3, p. 95-103, 2002.

BARROS, D. D.; LOPES, R. E.; GALHEIGO, S. M. Terapia Ocupacional Social: concepçóes e perspectivas. In: CAVALCANTI, A.; GALVÃO, C. Terapia Ocupacional: fundamentação \& prática. Rio de Janeiro: Guanabara Koogan, 2007. p. 347-353. 
CHAUÍ, M. Cultura e democracia. Revista latinoamericana de Ciencias Sociales, Buenos Aires, año 1, n. 1, p. 53-76, 2008.

COSTA, M. C. Arte de rua e Terapia Ocupacional: problematizando os desafios da sociedade neoliberal. In: CONGRESSO BRASILEIRO DE TERAPIA OCUPACIONAL, 7., 2001, Porto Alegre. Anais... Porto Alegre: Instituto Porto Alegre, 2001. p. 03-208.

COSTA, M. R. Culturas juvenis, globalização e localidades. In: COSTA, M. R.; SILVA, E. M. Sociabilidade juvenil e cultura urbana. São Paulo: Educ, 2006. p. 11-27.

COSTA, S. L. Terapia ocupacional Social: dilemas e possibilidades da atuação junto a povos e comunidades tradicionais. Cadernos de Terapia Ocupacional da UFSCar, São Carlos, v. 20, n. 1, p. 43-54, 2012.

DAYRELL, J. O jovem como sujeito social. In: FÁVERO, O. (Org.). Juventude e contemporaneidade. Brasília: UNESCO, 2007. p. 40-52.

DELEUZE, G.; GUATTARI, F. Mil platôs. Capitalismo e esquizofrenia. São Paulo: Editora 34, 1997.

DIÓGENES, G. Cartografias da cultura e da violência: gangues, galeras e o movimento hip hop. São Paulo: Annablume, 2008.

DORNELES, P. S.; PASIN, C. P. N.; FONSECA, L. A. A ética-estética da cultura hip hop e a Terapia Ocupacional: diálogos possíveis entre a arte resistência e a atividade terapêutica. In: CONGRESSO BRASILEIRO DE TERAPIA OCUPACIONAL, 9., 2005, Recife. Anais... Recife: UFPE, 2005, CD-ROM.

FOUCAULT, M. História da sexualidade 2: o uso dos prazeres. Rio de Janeiro: Paz e Terra, 1984.

FOUCAULT, M. Segurança, território e população. São Paulo: Martins Fontes, 2008.

FREIRE FILHO, J. Reinvençôes da resistência juvenil: os estudos culturais e as micropolíticas do cotidiano. Rio de Janeiro: Mauad X, 2007.

FUNDAÇÃO SISTEMA ESTADUAL DE ANÁLISE DE DADOS - SEADE. Índice de vulnerabilidade juvenil 2000-2005. São Paulo, 2007. Disponível em: <www. seade.gov.br>. Acesso em: 5 jan. 2011.

GALHEIGO, S. M. O social: idas e vindas de um campo de ação em Terapia Ocupacional. In: PÁDUA, E. M. M.; MAGALHÁES, L. V. Terapia Ocupacional: teoria e prática. Campinas: Papirus, 2003. p. 29-46.

GUATTARI, F. Caosmose: um novo paradigma estético. São Paulo: Editora 34, 2006.

GUATTARI, F.; ROLNIK, S. Micropolitica: cartografias do desejo. Petrópolis: Vozes, 2008.

HERSCHMANN, M. O funk e o hip-hop invadem a cena. Rio de Janeiro: Editora da UFRJ, 2000.

HERSCHMANN, M.; GALVÃO, T. Algumas considerações sobre a cultura hip hop no Brasil hoje. In: BO-
RELLI, S. H. S.; FREIRE FILHO, J. (Orgs.). Culturas juvenis no século XXI. São Paulo: Educ, 2008. p. 195210.

LAPLATINE, F. Aprender antropologia. São Paulo: Brasiliense, 2000.

MACEDO, M. D. C.; BARROS, D. D. Saúde e serviços assistenciais na experiência de jovens Guarani da comunidade Boa Vista. Revista de Terapia Ocupacional da Universidade de Sáo Paulo, São Paulo, v. 21, n. 3, p. 182-188, 2010

MAGNANI, J. G. C. De perto e de: notas para uma etnografia urbana. Revista Brasileira de Ciências Sociais, São Paulo, v. 17, n. 49, p. 11-29, 2002.

MEIHY, J. C. S. B.; HOLANDA, F. História oral: como fazer, como pensar. São Paulo: Contexto, 2010.

MOASSAB, A. Brasil periferia(s): a comunicação insurgente do hip-hop. São Paulo: Educ, 2011.

NARDI, H. C.; SILVA, R. N. Ética e subjetivação: as técnicas de si e os jogos de verdade contemporâneos. In: GUARESCHI, N. M. F. et al. (Org.). Foucault e a psicologia. Porto Alegre: Edipucrs, 2009. p. 93-105.

NASCIMENTO, E. P. Vozes marginais na literatura. Rio de Janeiro: Aeroplano, 2006.

NASCIMENTO, M. L.; COIMBRA, C. M. B. Juventude normatizada, moralizada e violentada: alguns modos de subjetivação contemporâneos. In: BOCAYUVA, H.; NUNES, S. A. (Org.). Juventudes, subjetivaçóes e violências. Rio de Janeiro: Contra Capa, 2009. p. 41-50.

NOVAES, R. Os jovens de hoje: contextos, diferenças e trajetórias. In: ALMEIDA, M. I. M. E.; EUGENIO, F. (Org.). Culturas Jovens: novos mapas do afeto. Rio de Janeiro: Zahar Editor, 2006. p. 105-120.

PAIS, J. M. Prefácio. Buscas de si: expressividades e identidades juvenis. In: ALMEIDA, M. I. M.; EUGÊNIO, F. (Org.). Culturas jovens: novos mapas do afeto. Rio de Janeiro: Jorge Zahar Editor, 2006. p. 7-21.

REGUILLO, R. En la calle outra vez: las bandas: identidad urbana y usos de la comunicación. México: Iteso, 1991.

SANTOS, M. Território e sociedade. Entrevista com Milton Santos. São Paulo: Fundação Perseu Abramo, 2000.

SÃO PAULO. Lei no 13.540, de 24 de março de 2003. Institui o Programa para a Valorizaçao de Iniciativas Culturais - VAI - no ambito da Secretaria Municipal de Cultura, e da outras providencias. Diário Oficial do $\mathrm{Mu}$ nicípio de São Paulo, São Paulo, 25 mar. 2003.

SILVA, G. Deleuze, Guattari e as cidades. Polêm!ca Revista Eletrônica, Rio de Janeiro, v. 8, n. 4, p. 184-191, 2009.

SPÓSITO, M. P. O Estado da Arte sobre juventude na pós-graduação brasileira: educação, ciências sociais e serviço social (1999-2006). Belo Horizonte: Argumentum, 2009. 
TAKEITI, B. A. Juventudes, subjetivações e violências: inventando modos de existência no contemporâneo. 2014. 225 f. Tese (Doutorado em Psicologia Social) - Universidade Católica de São Paulo, São Paulo, 2014.

TAKEUTI, N. Refazendo a margem pela arte e política. Revista Nômadas, Bogotá, v. 32, p. 13-25, 2010.

TAKEUTI, N. Dobras na juventude e nomadismo. Revista Latitudes, Alagoas, v. 6, n. 1, p. 7-23, 2012.

TOMMASI, L. Culturas de periferia: entre o mercado, os dispositivos de gestão do agir político. In: CONGRESSO INTERNACIONAL DA ASSOCIAÇÃO LATINO-AMERICANA DE SOCIOLOGIA, 28., Recife. Anais... Recife: UFPE, 2011.

TOMMASI, L. Nem bandidos nem trabalhadores baratos: trajetórias de jovens da periferia de Natal. Revista de Estudos de Conflito e Controle Social, Rio de Janeiro, v. 5, n. 1, p. 101-129, 2012.
TRASSI, M. L.; MALVASI, P. A. Violentamente pacificos: desconstruindo a associação juventude e violência. São Paulo: Editora Cortez, 2010.

VELAZCO, D.; TOMMASI, L. A produção de um novo regime discursivo sobre as favelas cariocas e as muitas faces do empreendedorismo de base comunitária. Revista do Instituto de Estudos Brasileiros, São Paulo, n. 56, p. 15-42, 2013.

VIANNA, H. O mundo do funk carioca. Rio de Janeiro: Jorge Zahar Editor, 1997.

WELLER, V. Minha vozé tudo o que eu tenho: manifestaçôes juvenis em Berlim e São Paulo. Belo Horizonte: Editora da UFMG, 2011.

YÚDICE, G. A conveniência da cultura: usos da cultura na era global. Belo Horizonte: Editora UFMG, 2013.

ZALUAR, A. Da revolta ao crime S/A. São Paulo: Editora Moderna, 1996.

\section{Contribuição dos Autores}

Beatriz Akemi Takeiti: foi responsável pela concepção do texto, organização de fontes e análises, redação e revisão. Maria Cristina Gonçalves Vicentin: foi responsável pela concepção, análise e revisão. Ambas autoras aprovaram a versão final do texto.

\section{Fonte de Financiamento}

Pesquisa recebeu financiamento pela CAPES.

\section{Notas}

${ }^{1}$ Este artigo é resultante da segunda parte da tese de doutorado intitulada Juventudes, subjetivação e violências - inventando modos de existência no contemporâneo, defendida em abril de 2014 no Programa de Estudos Pós-Graduados em Psicologia Social, sob orientação da Profa. Dra. Maria Cristina Gonçalves Vicentin. Por se tratar de pesquisa envolvendo seres humanos, o estudo foi submetido à avaliação do Comitê de Ética em Pesquisa (CEP-PUC/SP) e aprovado com parecer favorável à sua realização, Protocolo no. 377/11.

${ }^{2}$ Mais do que um espaço geográfico, o território compreende o lugar da existência humana, particular, no qual nos sentimos confortáveis. Ele pode ser relativo tanto ao espaço vivido quanto ao sistema percebido no seio do qual um sujeito se sente "em casa" (GUATTARI; ROLNIK, 2008). Para Adorno (1993), os processos de desterritorialização ocorrem à medida que sujeitos deixam suas identidades personalógicas familiares, institucionais, rígidas para entrar em linhas de fuga da ordem social. Um duplo mecanismo de funcionamento incide sobre este processo: de um lado, há o abandono progressivo de espaços institucionais da ordem moral e familiar dominante, e, de outro, a inscriçấo dos sujeitos em microterritórios, solo no qual constroem o essencial de suas existências.

3 Transcrição, textualização e transcriação constituem-se em procedimentos metodológicos, fazendo parte do arcabouço procedimental da história oral proposta por Meihy e Holanda (2010).

${ }^{4}$ Tomamos a ideia de estética aqui não para narrar o culto à beleza ou o gozo pela vida, mas, à luz do pensamento foucaultiano, como resistências/existências ao produzir "modos éticos e criativos de estar no mundo" (NARDI; SILVA, 2009, p. 47), como capacidade do homem em deixar-se afetar sensivelmente pelo outro e pelo mundo. Este é o elemento que compõe as práticas de estetização como um modo de reflexão da liberdade, onde os processos de subjetivação vão se atualizando ao construir a própria experiência.

5 Segundo Nascimento (2006), o termo literatura marginal foi cunhado por escritores da periferia de São Paulo para designar uma atuação cultural específica relacionada a um conjunto de experiências e elaboraçōes compartilhadas sobre os processos de marginalização nesses territórios, estabelecendo assim um vínculo entre criação literária e realidade social.

${ }^{6}$ A Fabicine tem como objetivo mediar diversos olhares a partir de encontros teóricos e práticos sobre as linguagens audiovisuais, com a finalidade de oferecer um estudo sobre a produção cinematográfica e videográfica. Configura-se como uma proposta de interlocuçáo entre o cinema e a comunidade, tendo o cinema como uma ferramenta política e instrumentalizadora para uma discussão local e do cotidiano dessa comunidade. 